\title{
TaS2 back contact improving oxide-converted Cu2BaSnS4 solar cells
}

Crovetto, Andrea; Børsting, Kristine; Nielsen, Rasmus; Hajijafarassar, Alireza; Hansen, Ole; Seger, Brian; Chorkendorff, Ib; Vesborg, Peter C.K.

Published in:

Applied Energy Materials

Link to article, DOI:

10.1021/acsaem.9b02251

Publication date:

2020

Document Version

Peer reviewed version

Link back to DTU Orbit

Citation (APA):

Crovetto, A., Børsting, K., Nielsen, R., Hajijafarassar, A., Hansen, O., Seger, B., Chorkendorff, I., \& Vesborg, P. C. K. (2020). TaS back contact improving oxide-converted $\mathrm{Cu}_{2} \mathrm{BaSnS}_{4}$ solar cells. Applied Energy Materials, 3(1), 1190-1198. Rttps://doi.org/10.1021/acsaem.9b02251

\section{General rights}

Copyright and moral rights for the publications made accessible in the public portal are retained by the authors and/or other copyright owners and it is a condition of accessing publications that users recognise and abide by the legal requirements associated with these rights.

- Users may download and print one copy of any publication from the public portal for the purpose of private study or research.

- You may not further distribute the material or use it for any profit-making activity or commercial gain

- You may freely distribute the URL identifying the publication in the public portal 


\title{
Acs APPLIED ENERGY MATERIA
}

\section{Article}

\section{A TaS back contact improving oxide-converted CuBaSnS solar cells}

\author{
Andrea Crovetto, Kristine Børsting, Rasmus Nielsen, Alireza Hajijafarassar, \\ Ole Hansen, Brian Seger, Ib Chorkendorff, and Peter C. K. Vesborg
}

ACS Appl. Energy Mater., Just Accepted Manuscript • DOI: 10.1021/acsaem.9b02251 • Publication Date (Web): 18 Dec 2019

Downloaded from pubs.acs.org on December 27, 2019

\section{Just Accepted}

"Just Accepted" manuscripts have been peer-reviewed and accepted for publication. They are posted online prior to technical editing, formatting for publication and author proofing. The American Chemical Society provides "Just Accepted" as a service to the research community to expedite the dissemination of scientific material as soon as possible after acceptance. "Just Accepted" manuscripts appear in full in PDF format accompanied by an HTML abstract. "Just Accepted" manuscripts have been fully peer reviewed, but should not be considered the official version of record. They are citable by the Digital Object Identifier (DOI®). "Just Accepted" is an optional service offered to authors. Therefore, the "Just Accepted" Web site may not include all articles that will be published in the journal. After a manuscript is technically edited and formatted, it will be removed from the "Just Accepted" Web site and published as an ASAP article. Note that technical editing may introduce minor changes to the manuscript text and/or graphics which could affect content, and all legal disclaimers and ethical guidelines that apply to the journal pertain. ACS cannot be held responsible for errors or consequences arising from the use of information contained in these "Just Accepted" manuscripts. 


\title{
A $\mathrm{TaS}_{2}$ back contact improving
}

\section{oxide-converted $\mathrm{Cu}_{2} \mathrm{BaSnS}_{4}$ solar cells}

\author{
Andrea Crovetto, ${ }^{*, \dagger} \uparrow$ Kristine Børsting, ${ }^{\dagger}$ Rasmus Nielsen, ${ }^{\dagger}$ Alireza Hajijafarassar ${ }^{\ddagger}$ \\ Ole Hansen, ${ }^{\ddagger}$ Brian Seger ${ }^{\dagger}$ Ib Chorkendorff, $^{\dagger}$ and Peter C. K. Vesborg*, ${ }^{*}$ \\ $\dagger$ †urfcat, DTU Physics, Technical University of Denmark, DK-2800 Kgs. Lyngby, Denmark \\ $\ddagger D T U$ Nanolab, Technical University of Denmark, DK-2800 Kgs. Lyngby, Denmark \\ ๆCurrent address: Helmholtz-Zentrum Berlin für Materialien und Energie GmbH, \\ Glienicker Str. 100, 14109 Berlin, Germany. \\ E-mail: andrea.crovetto@helmholtz-berlin.de; Peter.Vesborg@fysik.dtu.dk
}

\begin{abstract}
Solar cells based on the wide band-gap $\mathrm{Cu}_{2} \mathrm{BaSnS}_{4}$ (CBTS) photoabsorber have achieved open circuit voltages up to $1.1 \mathrm{~V}$ over a short development period, making CBTS an attractive material for tandem photovoltaic and photoelectrochemical cells. In this work, we explore an alternative CBTS growth route based on oxide precursors, and we propose $\mathrm{TaS}_{2}$ as an alternative back contact material to the commonly used $\mathrm{Mo} / \mathrm{MoS}_{2}$. The oxide precursor route does not require higher sulfurization temperatures than other more common fabrication routes, and it yields CBTS films with negligible Stokes shift between photoluminescence maximum and band gap energy, while at the same time avoiding sulfur contamination of vacuum systems. The high work-function metallic $\mathrm{TaS}_{2}$ compound is selected as a prospective hole-selective contact, which could also prevent the losses associated with carrier transport across the semiconducting $\mathrm{MoS}_{2}$ layer. By comparing CBTS solar cells with $\mathrm{Mo}$ and $\mathrm{TaS}_{2}$ back contacts, the latter shows


a significantly lower series resistance, resulting in a 10\% relative efficiency improvement. Finally, we fabricate a proof-of-concept monolithic CBTS/Si tandem cell using a thin $\mathrm{Ti}(\mathrm{O}, \mathrm{N})$ interlayer intended both as a diffusion barrier and as a recombination layer between the two subcells.

\section{Keywords}

kesterite, cation substitution, wide band gap absorber, tandem solar cell, silicon, back contact, $\mathrm{TaS}_{2}$, sputtering

\section{Introduction}

As single-junction silicon solar cells approach their theoretical efficiency limit, one of the most compelling strategies for continuing to improve solar energy conversion efficiency is the tandem solar cell architecture, featuring a wide band-gap thin-film cell on top of a silicon cell. ${ }^{1}$ However, finding a suitable 1.6-2.0 eV band-gap top absorber that can deliver an open circuit voltage $\left(V_{\mathrm{oc}}\right)$ well above $1 \mathrm{~V}$ has proven challenging. Together with the intensively researched class of halide perovskite photoabsorbers, the air-stable $\mathrm{Cu}_{2} \mathrm{BaSnS}_{4}$ (CBTS) compound has recently emerged as one of the very few non-epitaxially grown materials able to break the $1 \mathrm{~V} V_{\mathrm{oc}}$ barrier under 1 sun illumination. ${ }^{2-5}$ As the total number of CBTS-related publications $(\sim 10 \text { articles })^{5-13}$ is about three orders of magnitude smaller than the size of the halide perovskite literature, there may be substantial opportunities for further optimization of growth processes and device design. In fact, only two routes for the synthesis of CBTS films have been reported: sputtering of metallic/sulfide targets ${ }^{5,7,8}$ and spin-coating of precursor salts followed by sulfurization. ${ }^{6}$ Alternative reaction pathways, as well as different vacuum-based ${ }^{14,15}$ and solution-based ${ }^{16,17}$ deposition techniques may deserve investigation, as they have been employed successfully in chemically-related absorbers. ${ }^{14-17}$ In a similar fashion, only two variations of the archetypical Mo/absorber/CdS/ZnO device 


\section{Results and discussion}

\section{CBTS from oxide precursors}

CBTO precursor films are deposited on both Mo-coated and Ta-coated soda lime glass (SLG) substrates by cosputtering $\mathrm{Cu}, \mathrm{Ba}$, and $\mathrm{Sn}$ metallic targets in a reactive $\left(1.5 \% \mathrm{O}_{2}\right.$ in $\left.\mathrm{Ar}\right)$ atmosphere. With this process route, sulfur contamination of vacuum systems and highcost, low sputter-rate ceramic sulfide targets are avoided. As-deposited CBTO films do not exhibit x-ray diffraction (XRD) peaks other than those from Mo or Ta (Fig. S1, Supporting Information). According to energy-dispersive x-ray spectroscopy (EDX), their typical oxygen content is around $50 \%$ (atomic) as expected for stoichiometric CBTO. The precursors are then sulfurized in $5 \% \mathrm{H}_{2} \mathrm{~S}$ in Ar. As shown by both EDX and x-ray photoemission spectroscopy (XPS), the oxide films are completely converted into sulfides after sulfurization at 
$540^{\circ} \mathrm{C}$ for $5 \mathrm{~min}$ (Fig. 1(c)). The CBTO precursor compositional window yielding the most efficient solar cells is found by experiment in the strongly $\mathrm{Cu}$-poor and moderately Ba-rich region (Fig. 1(a)). For cells with a Mo back contact, the highest efficiency is obtained for $\mathrm{Cu} /(\mathrm{Ba}+\mathrm{Sn})=0.48 \pm 0.02$ and $\mathrm{Ba} / \mathrm{Sn}=1.16 \pm 0.04$ followed by sulfurization at $550^{\circ} \mathrm{C}$ for 30 min. For the case of a $\mathrm{Ta} / \mathrm{TaS}_{2}$ back contact, the best cells have precursor composition $\mathrm{Cu} /(\mathrm{Ba}+\mathrm{Sn})=0.60 \pm 0.02, \mathrm{Ba} / \mathrm{Sn}=1.23 \pm 0.04$ and are sulfurized at $540^{\circ} \mathrm{C}$ for $5 \mathrm{~min}$. In the closely related compound $\mathrm{Cu}_{2} \mathrm{SrSnS}_{4}$ (CSTS) grown by the same method, ${ }^{25}$ the optimal composition was $\mathrm{Cu} /(\mathrm{Sr}+\mathrm{Sn}) \sim 0.7$ and $\mathrm{Sr} / \mathrm{Sn} \sim 1.2$ with sulfurization at $520^{\circ} \mathrm{C}$ for 5 min. In all the above cases, the composition is significantly more $\mathrm{Cu}$-poor than in previous studies on CBTS grown by other methods, which typical report an optimal precursor composition in the $0.8<\mathrm{Cu} /(\mathrm{Ba}+\mathrm{Sn})<0.95$ range, combined with similar sulfurization temperatures of $540-580^{\circ}$ C..$^{5,11,26}$ To try to explain those discrepancies, we first observe from Fig. 1(a) that the optimal precursor composition in our studies shifts towards more extreme Cu substoichiometry as the sulfurization temperature and time increase. Secondly, the film composition after sulfurization appears to be much closer to the stoichiometric point than the precursor composition (Fig. 1(a)). However, comparison of Fig. 1(b) with Fig. 1(c) indicates that significant elemental redistribution occurs during sulfurization, as the top half of the CBTS film is much less Cu-poor than the bottom half. Since EDX has a finite analysis depth, this may be the main reason for the apparent stoichiometry change detected by EDX. Inhomogeneous composition across the film thickness was also observed for CSTS films grown by the same method $^{25}$ but the effect is more pronounced here for CBTS. 


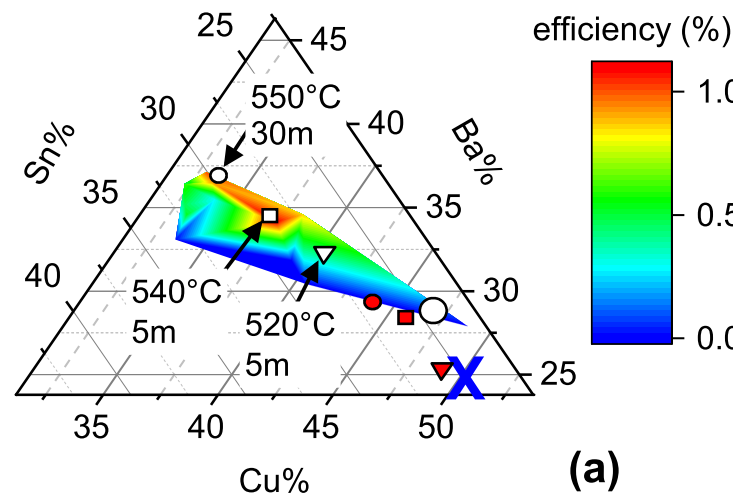

(a)
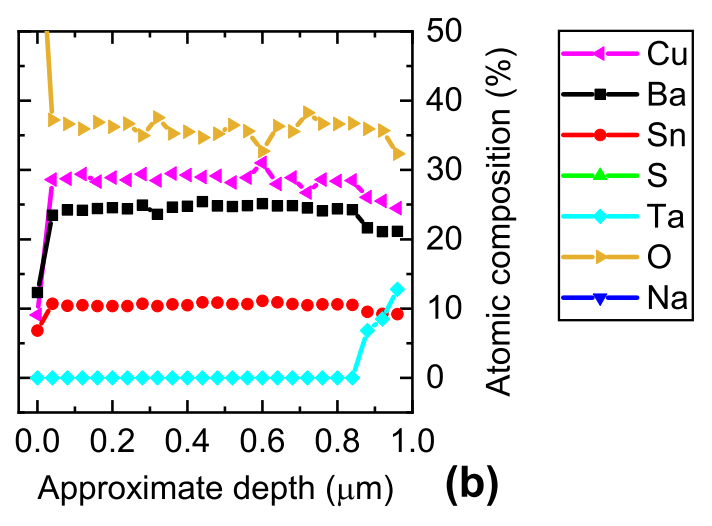

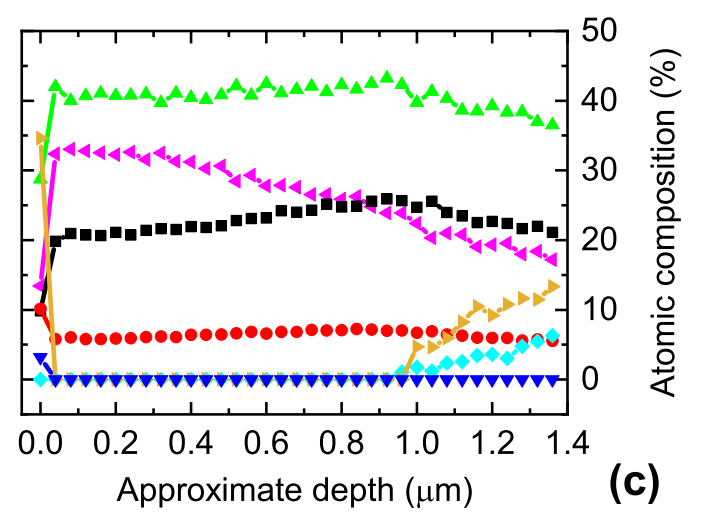

Figure 1: (a): Atomic metal composition of different CBTO precursor films before sulfurization, according to EDX. The color at each composition indicates the highest efficiency achieved by CBTS solar cells with that precursor composition. The map is based on 13 compositions from films grown on both Mo and Ta. The $(\mathrm{Cu}+\mathrm{Ba}+\mathrm{Sn})$ composition is normalized to 1 and the blue cross indicates the stoichiometric composition. The small white markers indicate the optimal precursor compositions under different sulfurization conditions; the corresponding compositions measured after sulfurization are indicated by the red markers. The bigger white circle is the optimal precursor composition typically reported in previous work on CBTS by other synthesis methods. ${ }^{611}$ (b-c) Depth-dependent composition of CBTO (b) and of CBTS (c) on a Ta back contact by XPS sputter profiling. Note that the absolute values of the XPS-determined composition are not to be taken quantitatively due to preferential sputtering effects of the $\mathrm{Ar}^{+}$ion beam used for profiling, which are especially large for Sn. ${ }^{24}$ 
A possible explanation for the surprisingly $\mathrm{Cu}$-poor optimal precursor composition and for elemental redistribution upon sulfurization could be a surface decomposition reaction similar to the case of the related absorber $\mathrm{Cu}_{2} \mathrm{ZnSnS}_{4}$ (CZTS), resulting in the loss of $\mathrm{SnS}$ by evaporation at high sulfurization temperatures. ${ }^{27}$ However, if this hypothesis were correct, BaS evaporation would have to be even faster than $\mathrm{SnS}$ evaporation to be consistent with the composition change before and after sulfurization (Fig. 1(a)). This is unlikely, as $\mathrm{BaS}$ is less volatile than SnS. ${ }^{28}$ Furthermore, major $\mathrm{Sn}$ or Ba losses were not observed in previous processes involving sulfide/metallic precursors to CBTS, even though the sulfurization temperature was typically higher. ${ }^{6,11,26}$ As the optimal precursor composition and the CBTS secondary phase mix is also found to depend on the back contact material (Fig. 2), it can be interesting to formulate some hypotheses for the observed behavior. A first possibility is that $\mathrm{Cu}$ diffuses towards the surface of CBTS during sulfurization, as was shown for non-oxide precursors. ${ }^{9}$ There, a Cu-rich surface was formed at relatively low temperatures $\left(250-400^{\circ} \mathrm{C}\right)$ but $\mathrm{Cu}$ re-diffused evenly across the film starting from $450^{\circ} \mathrm{C}$. As $\mathrm{Cu}-\mathrm{O}$ bonds are stronger than $\mathrm{Cu}-\mathrm{S}$ bonds, ${ }^{28} \mathrm{Cu}$ diffusion might require higher temperatures when oxide precursors are used, which could prevent the re-diffusion process. Since a Cu-rich composition is detrimental for solar cell performance due to the defect chemistry of CBTS, ${ }^{12}$ a very $\mathrm{Cu}$-poor precursor composition is necessary to delay the formation of a Cu-rich layer at the film surface. With an extremely Cu-poor composition left at the bottom of the film, different back contact materials may catalyze different interface reactions leading to different secondary phase mixes, an effect that is well documented for CZTS. ${ }^{29}$ A second possiblity is that Na impurities from the SLG substrate have different diffusion kinetics through different back contacts. Since Na is known to promote grain growth and elemental redistribution in CZTS, ${ }^{30}$ differences in Na impurity content during CBTS formation may influence its secondary phase mix. In fact, even a small Ge impurity content was shown to strongly modify the formation pathway of CZTS. ${ }^{31}$ Regardless of which particular mechanism is dominant, the need for strongly $\mathrm{Cu}$-poor precursors seems to be a unique characteristic of the oxide 
precursor route to the synthesis of CBTS and CSTS.

As expected from the precursor composition, XRD peaks related to $\mathrm{Ba}_{2} \mathrm{SnS}_{4}$ secondary phases, as well as weak peaks possibly belonging to $\mathrm{BaS}_{2}$ and $\mathrm{BaS}_{3}$, are detected in CBTS films on both Mo and Ta (Fig. 2). All the main peaks expected for trigonal CBTS ${ }^{13}$ are present using both back contacts, without preferential orientation effects. Peaks related to $\mathrm{MoS}_{2}$ and $\mathrm{TaS}_{2}$ crystallites with the c-axis perpendicular to the substrate plane are also observed below $15^{\circ} 2 \theta$ in Fig. 2 . As for the case of CSTS grown by the oxide precursor route,$^{25}$ we were not able to grow single-phase CBTS films even when employing stoichiometric precursors and/or lower sulfurization temperatures.

Although it was found previously that $\mathrm{Sr}_{2} \mathrm{SnS}_{4}$ secondary phases in CSTS could be etched by sonication in water, ${ }^{25}$ we were not able to etch $\mathrm{Ba}_{2} \mathrm{SnS}_{4}$ in CBTS. The etchability of $\mathrm{Sr}_{2} \mathrm{SnS}_{4}$ was attributed to its large $\mathrm{Na}$ impurity content from the soda lime glass substrate. However, Na impurites in CBTS films are only detected at the surface (Fig. 1(c)) as in typical $\mathrm{Cu}_{2} \mathrm{ZnSnS}_{4}$ films, ${ }^{30}$ and no Na-containing $\mathrm{Ba}_{2} \mathrm{SnS}_{4}$ phases could not be found by scanning electron microscopy (SEM) and EDX. While no experimental references could be found for the band gap of $\mathrm{Ba}_{2} \mathrm{SnS}_{4}$, computational methods that tend to underestimate band gaps ${ }^{32}$ predict a band gap of $2.5 \mathrm{eV}$. Since CBTS has a lower band gap, $\mathrm{Ba}_{2} \mathrm{SnS}_{4}$ is not expected to cause carrier trapping, even though it may degrade carrier collection efficiency and series resistance in a solar cell.

The CBTS film surface morphology, both on Mo and on Ta, consists of densely packed crystal grains around $1 \mu \mathrm{m}$ in size without apparent phase segregation (Fig. 3(a,b)). This observation is in agreement with the tendency of $\mathrm{Cu}$ to diffuse towards the top of the film and form stoichiometric CBTS, as noted above. Interestingly, the significant composition gradient across the film thickness does not result in an obvious morphology change from the top to the bottom of the film (Figs. 3(d,e)). Especially for the case of CBTS on Mo (Fig. 3(d)), individual crystal grains appear to span the whole film thickness, whereas some voids and smaller grains are visible for CBTS on Ta near the back interface (Fig. 3(e)). 


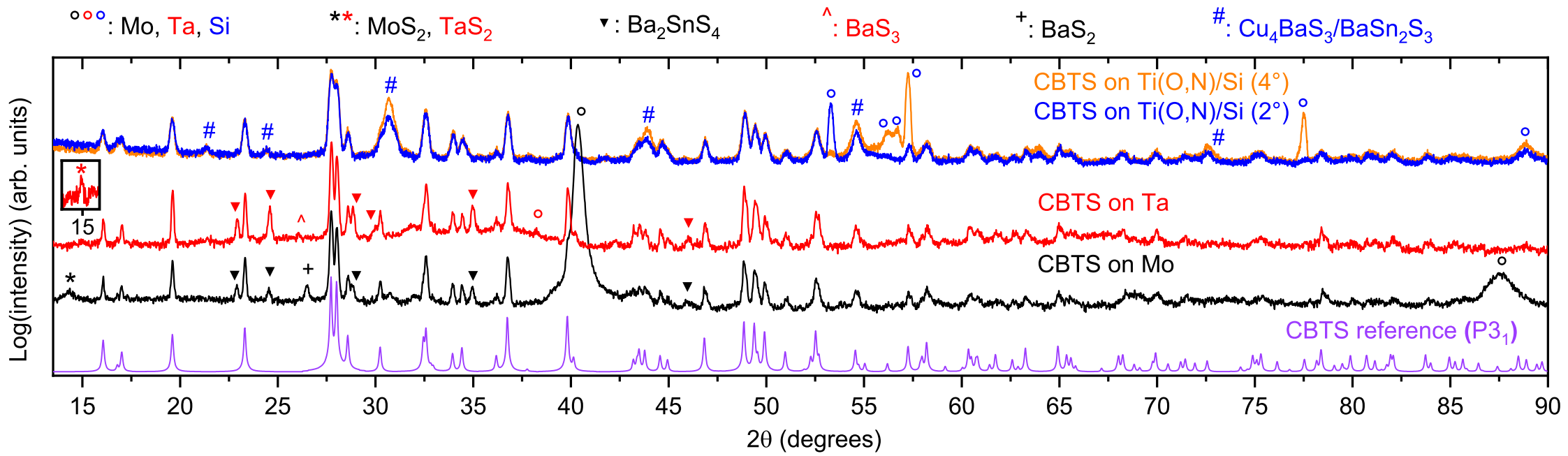

Figure 2: From bottom to top: reference XRD pattern of randomly-oriented trigonal CBTS (space group $P 3_{1}$, collection code 52267 from the Inorganic Crystal Structure Database, ICSD); ${ }^{13}$ XRD patterns of two CBTS films on Mo and on Ta, taken with a standard Bragg-Brentano measurement geometry; XRD patterns of CBTS grown on a Ti(O,N) layer deposited on a Si bottom cell, taken with a grazing incidence geometry at $4^{\circ}$ and $2^{\circ}$ incidence angles. The larger width of the CBTS peaks on the Si bottom cell is due to additional instrumental broadening in the grazing incidence configuration. The peaks labeled with a downward triangle are attributed to $\mathrm{Ba}_{2} \mathrm{SnS}_{4}$ due to their small shift towards lower angles with respect to the $\mathrm{Sr}_{2} \mathrm{SnS}_{4}$ secondary phase observed in CSTS films (Fig. S2, Supporting Information). The peaks labeled with a hash could be attributed to both $\mathrm{Cu}_{4} \mathrm{BaS}_{3}$ and $\mathrm{BaSn}_{2} \mathrm{~S}_{3}$ (Fig. S3, Supporting Information). The inset for the XRD pattern on Ta is a slower XRD scan around $15^{\circ} 2 \theta$, where the $\mathrm{TaS}_{2}$ (001) reflection is expected (Fig. S4, Supporting Information). 

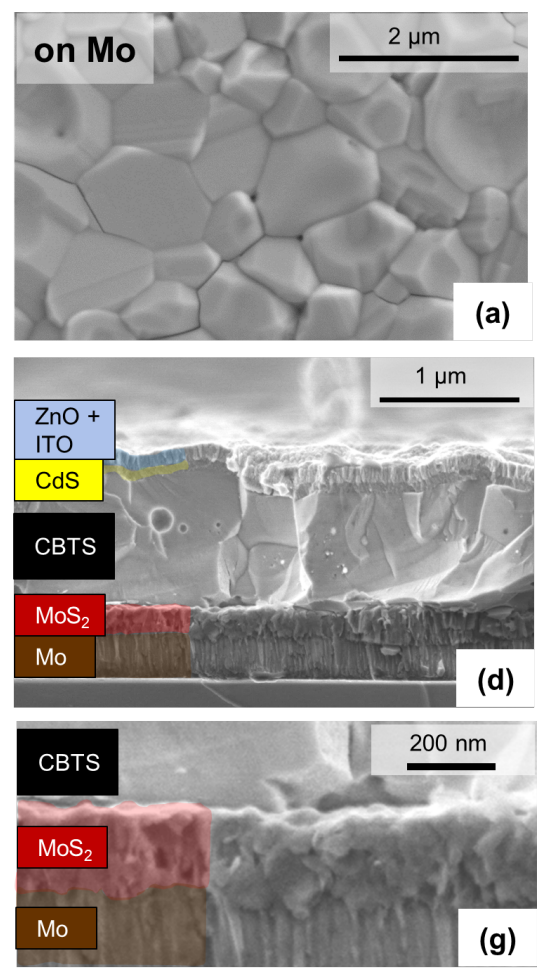
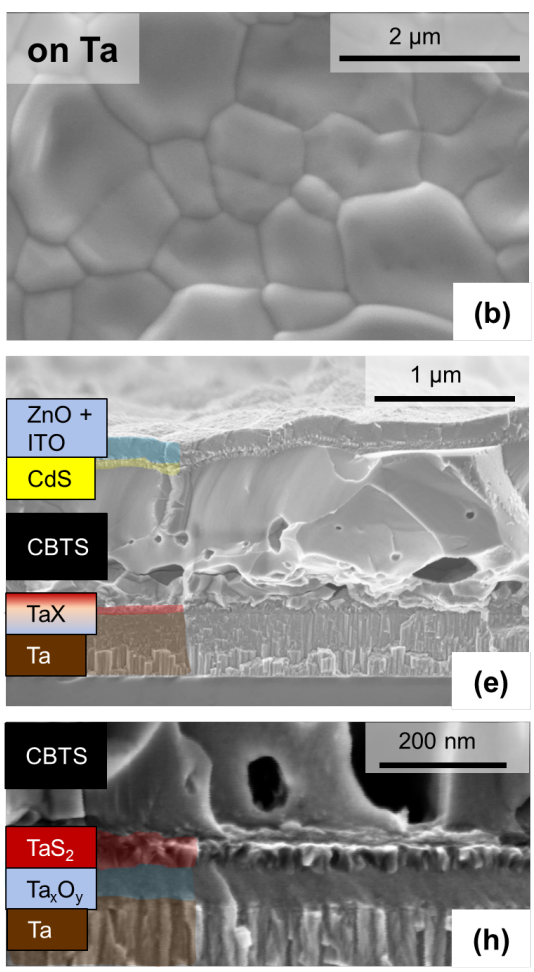
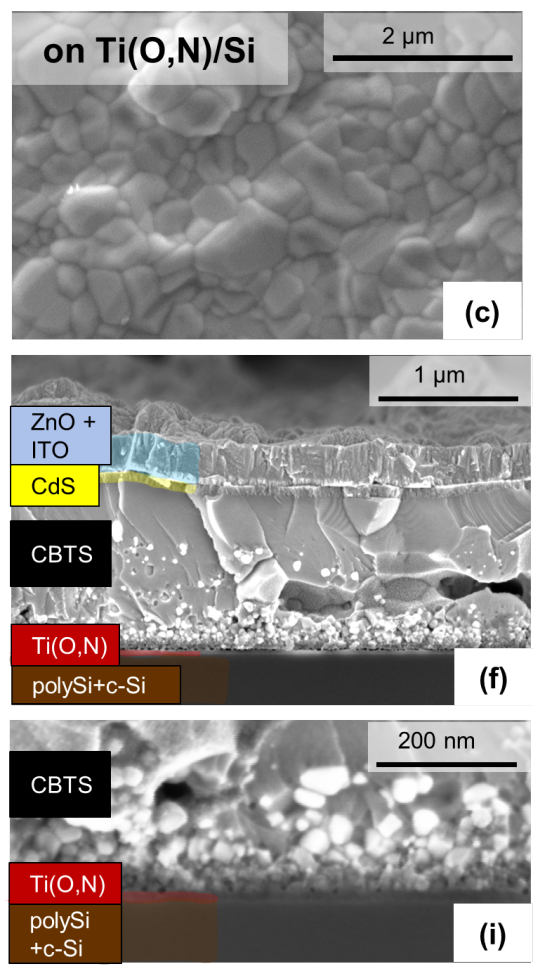

Figure 3: Top row: Top-view SEM images of CBTS films grown on Mo (a), Ta (b) and $\mathrm{Ti}(\mathrm{O}, \mathrm{N}) /$ polySi/c-Si (c). Middle row: Cross-sectional SEM images of single-junction CBTS solar cells with a Mo (d) or Ta (e) back contact, and of a tandem CBTS/Si solar cell with a $\mathrm{Ti}(\mathrm{O}, \mathrm{N})$ recombination layer (f). Bottom row: high-resolution SEM images around the interface between CBTS and the Mo $(\mathrm{g})$ or Ta $(\mathrm{h})$ back contact or the $\mathrm{Ti}(\mathrm{O}, \mathrm{N})$ recombination layer (i). The top part of the Ta back contact (h) reacts to form two thin layers identified attributed to $\mathrm{TaS}_{2}$ (top) and a Ta oxide (bottom). Near the interface with $\mathrm{Ti}(\mathrm{O}, \mathrm{N}$ ) (i) nanocrystalline secondary phases attributed to $\mathrm{Cu}_{4} \mathrm{BaS}_{3}$ and/or $\mathrm{BaSn}_{2} \mathrm{~S}_{3}$ (Fig. S3, Supporting Information) are present.

Similarly to previous reports, ${ }^{5-7}$ the band gap of CBTS is found here to be around $2.0 \mathrm{eV}$ by various experimental methods (Fig. 4). As noted by others, ${ }^{5-7}$ the room-temperature photoluminescence peak of CBTS is well aligned to its band gap with negligible Stokes shift (Fig. 4), unlike the case of the more thoroughly investigated CZTS absorber. Furthermore, the full width at half maximum (FWHM) of the PL peak is significantly narrower in CBTS than in CZTS ( 80 meV for CBTS versus 200-250 meV for device-grade CZTS). ${ }^{19}$ It is concluded that the investigated optoelectronic properties of CBTS produced via the proposed oxide precursor route are overall similar to the previously reported properties of CBTS produced by other routes, despite the presence of some secondary phases. It has been argued ${ }^{7,12}$ 


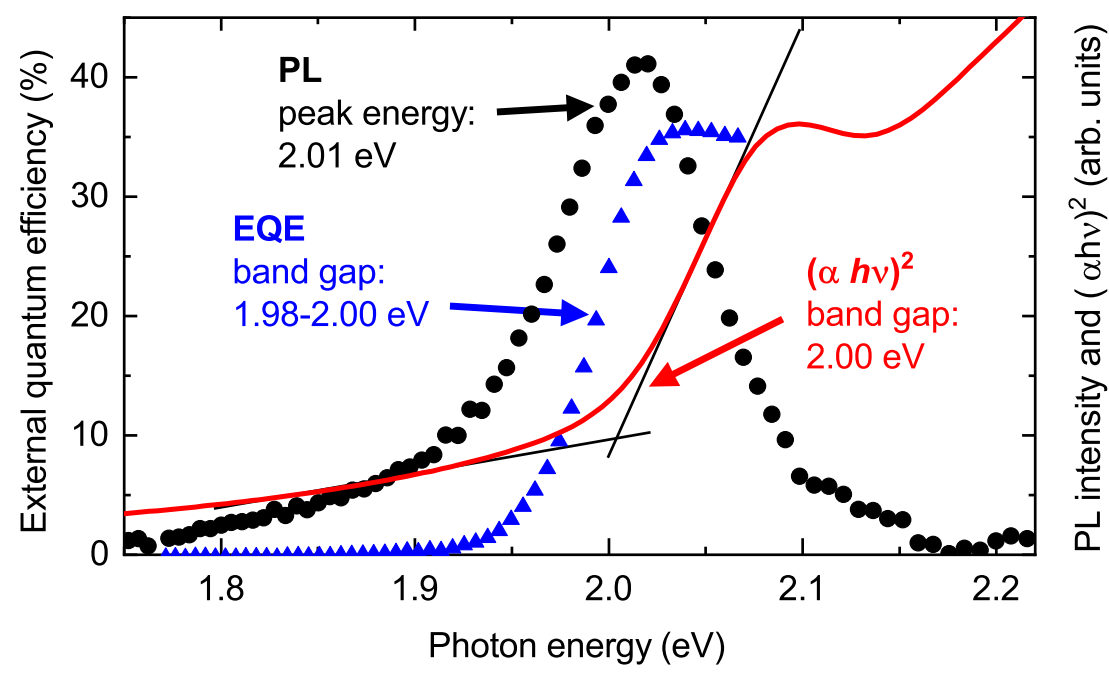

Figure 4: Direct band-gap Tauc plot of a CBTS film ( $\alpha$ is the ellipsometry-determined absorption coefficient and $\mathrm{h} \nu$ is the photon energy), EQE onset of a CBTS solar cell, and room-temperature PL of a CBTS film. Two band gap estimation methods are used for the EQE data, as shown in detail in Fig. S5, Supporting Information.

that the favorable PL features of CBTS may arise from the increase in the formation energy (i.e., lower concentration) of $\mathrm{X}_{\mathrm{Ba}}$ and $\mathrm{Bax}$ defects compared to $\mathrm{X}_{\mathrm{Zn}}$ and $\mathrm{Zn}_{\mathrm{X}}$ defects $(\mathrm{X}=$ $\mathrm{Cu}, \mathrm{Sn})$ due to the large ionic radius mismatch between $\mathrm{Ba}^{2+}$ and both $\mathrm{Cu}^{1+}$ and $\mathrm{Sn}^{4+}$. $\mathrm{Al}-$ though calculated defect formation energies confirm those arguments, ${ }^{12}$ we emphasize that a clear link between experimental defect densities and PL features has not been established yet.

The performance of CBTS solar cells based on oxide precursors is compared in Table 1 to the performance of the highest-efficiency CBTS solar cell reporting the same Mo/CBTS/CdS/ZnO device architecture. ${ }^{6}$ While the short circuit current $\left(J_{\mathrm{sc}}\right)$ is slightly higher for the case of the oxide precursors, the open circuit voltage $\left(V_{\mathrm{sc}}\right)$ and fill factor $(\mathrm{FF})$ are higher in the previous report. We assume that the very $\mathrm{Cu}$-poor precursor composition, with the associated compositional gradients and $\mathrm{Ba}_{2} \mathrm{SnS}_{4}$ phase segregation, may play a role in such losses. Detailed characterization of CBTO-to-CBTS reaction and experiments with intermediate hold steps during sulfurization could help understand whether less Cu-poor precursors can be employed successfully under different sulfurization conditions. 


\section{CBTS solar cells with a $\mathrm{Ta} / \mathrm{TaS}_{2}$ back contact}

The back contact typically employed in both CBTS and CZTS solar cells is Mo. ${ }^{6,7,9,19,33}$ While a Mo back contact has enabled efficiencies well above $20 \%$ for $\mathrm{Cu}(\mathrm{In}, \mathrm{Ga}) \mathrm{Se}_{2}$ solar cells, ${ }^{34}$ a significant efficiency boost was reported for CZTS cells when Mo was replaced by a high work-function metal $(\mathrm{Au})$ in combination with a high work-function hole transport layer $\left(\mathrm{MoO}_{3}\right){ }^{18}$ The improvement over the standard Mo back contact was mainly due to an improved FF, which was already believed to be limited by a Mo back contact barrier ${ }^{35}$ possibly due to the formation of a thick $\mathrm{MoS}_{2}$ layer during sulfurization. ${ }^{33} \mathrm{~A}$ disadvantage of the $\mathrm{Au} / \mathrm{MoO}_{3}$ back contact is its instability at the typical sulfurization temperatures employed for CZTS and CBTS. Therefore, a rather complicated fabrication process had to be devised, ${ }^{18}$ involving lift-off of the CZTS absorber from its original Mo back contact and deposition of a new $\mathrm{Au} / \mathrm{MoO}_{3}$ on the exposed back surface. To avoid the lift-off step, we propose $\mathrm{TaS}_{2}$ as a novel back contact for CBTS photoabsorbers, and possibly for other sulfide absorbers. Although a number of transition metal chalcogenides are stable high work-function metallic compounds, ${ }^{36}$ they have not been investigated as hole contacts for chalcogenide photoabsorbers, with the exception of a couple of studies on $\mathrm{VSe}_{2}, \mathrm{TiSe}_{2}$, and $\mathrm{NbSe}_{2}$ in CdTe solar cells. ${ }^{37,38}$ A number of compelling features are expected for $\mathrm{TaS}_{2}$ as a hole contact to CBTS:

1. Unlike the semiconducting $\mathrm{MoS}_{2}, \mathrm{TaS}_{2}$ is a high work-function metallic compound at room temperature. ${ }^{39}$ Its work function $(5.2 \mathrm{eV}$ for the $1 \mathrm{~T}$ phase, $5.6 \mathrm{eV}$ for the $2 \mathrm{H}$ phase $)^{36}$ matches the $\sim 5.5 \mathrm{eV}$ work function of p-type $\operatorname{CBTS}^{5,25}$ so Schottky-Mott theory predicts $\mathrm{TaS}_{2}$ to be an ohmic hole contact for CBTS. ${ }^{40}$

2. Similarly to the case of the standard $\mathrm{Mo} / \mathrm{MoS}_{2}$ back contact, a $\mathrm{TaS}_{2}$ layer may be expected to form during sulfurization of CBTS when CBTS is deposited on a metallic Ta film. Therefore, impractical lift-off/redeposition processes are avoided.

3. $\mathrm{TaS}_{2}$ is expected to be more stable than $\mathrm{Au} / \mathrm{MoO}_{3}$ during high-temperature sulfuriza- 
tion because Ta is a much less diffusive species than Au, and because a sulfide back contact is the desired reaction product instead of a byproduct. Also, a back contact sharing the (sulfur) anion with the absorber prevents potential anion interdiffusion issues, which were found to be detrimental for, e.g., the CdTe/ $\mathrm{NbSe}_{2}$ system. $^{38}$

4. The room-temperature resistivities reported for $1 \mathrm{~T}-\mathrm{TaS}_{2}$ and $2 \mathrm{H}-\mathrm{TaS}_{2}$ are $2 \times 10^{-3} \Omega \mathrm{cm}$ and $1 \times 10^{-3} \Omega \mathrm{cm}$ respectively. ${ }^{39,41}$ Although they are higher than typical resistivities of elemental metals and may be insufficient for lateral carrier transport, the unreacted Ta layer under $\mathrm{TaS}_{2}$ could provide such transport.

To verify if the potential advantages listed above are actually realized, CBTS is grown on Ta and back contact characterization is performed. While a $\sim 200 \mathrm{~nm} \mathrm{MoS}_{2}$ layer is formed on the Mo back contact (Figs. 2, 3(g)) similarly to CZTS solar cells, ${ }^{42}$ the case of a Ta back contact is more complex. Two intermediate layers are clearly visible between the Ta back contact and the CBTS absorber by SEM (Fig. 3(h)). The top layer is about $50 \mathrm{~nm}$ thick with similar morphology to the $\mathrm{MoS}_{2}$ layer; the bottom layer is about $80 \mathrm{~nm}$ thick and amorphous in appearance. By combining XRD and XPS data, we assign the two layers to $\mathrm{TaS}_{2}$ and to a Ta oxide respectively. The presence of $\mathrm{TaS}_{2}$ is deduced from its (001) XRD peak observed in Fig. S4(a), Supporting Information and reproduced the inset of Fig. 2. Determining the crystal structure of the $\mathrm{TaS}_{2}$ layer is not straightforward because the experimental (001) peak is weak and the $1 \mathrm{~T}-\mathrm{TaS}_{2}$ and $2 \mathrm{H}-\mathrm{TaS}_{2}$ structures have similar interlayer spacing along the c-axis. Although the experimental peak matches the $1 \mathrm{~T}-\mathrm{TaS}_{2}$ reference slightly better than the $2 \mathrm{H}-\mathrm{TaS}_{2}$ reference (Fig. S4(a), Supporting Information) $2 \mathrm{H}-\mathrm{TaS}_{2}$ is actually expected to be the most stable phase at annealing temperatures above $350^{\circ}$ C. ${ }^{36,39}$ In fact, Ta films sulfurized at higher temperatures consist mostly of $2 \mathrm{H}-\mathrm{TaS}_{2}$ (Fig. S4(e), Supporting Information).

No XRD peaks related to Ta oxides could be identified, possibly due to an amorphous film structure (Fig. 3(h)). The presence of $\mathrm{Ta}_{x} \mathrm{O}_{y}$ is however inferred from the XPS depth profile in Fig. 1(c), where an O signal appears together with the Ta signal once the CBTS 

in the Ta-O system, other stoichiometries are possible especially in thin film systems. ${ }^{43}$ We assume that, during sulfurization, part of the oxygen in the CBTO precursors is exchanged with sulfur and leaves the system in the gas phase, and another part oxidizes the top region of the Ta film. Once the temperature is high enough and all the CBTO has been converted into CBTS, the newly formed $\mathrm{Ta}_{\mathrm{x}} \mathrm{O}_{\mathrm{y}}$ starts reacting as well, with subsequent formation of $\mathrm{TaS}_{2}$ starting from the top. The top film in the $\mathrm{Ta}_{\mathrm{x}} \mathrm{O}_{\mathrm{y}} / \mathrm{TaS}_{2}$ stack is thus likely to be $\mathrm{TaS}_{2}$, also due to its similar morphology to the structurally-related $\mathrm{MoS}_{2}$ and to previously reported $\mathrm{TaS}_{2}$ interlayers. $^{44}$

The $\mathrm{TaS}_{2}$ back contact is found to be stable for a few minutes at sulfurization temperatures up to about $540^{\circ} \mathrm{C}$. Under more aggressive sulfurization conditions, Ta starts diffusing into CBTS according to EDX. The Ta diffusion process is accompanied by a visible color change of CBTS from grey-red to grey-green, as well as by major morphology changes in the CBTS film (Fig. S6, Supporting Information). On the other hand, no Mo interdiffusion is detected for sulfurization temperatures up to $580^{\circ} \mathrm{C}$, where fast $\mathrm{SnS}$ evaporation from CBTS becomes the main issue limiting the maximum practical sulfurization temperature. ${ }^{27}$

As the $\mathrm{TaS}_{2}$ film is buried under CBTS, it is difficult to characterize it further. Electrical measurements of a $\mathrm{TaS}_{2}$ film on Ta would also be affected by the underlying metallic layer. Therefore, we perform additional characterization on a $\mathrm{TaS}_{2}$ film on quartz obtained by fully sulfurizing a Ta film at $950^{\circ} \mathrm{C}$ for 2 hours. This film consists of $\mathrm{TaS}_{2}$ platelets (Fig. S7, Supporting Information) mainly in the $2 \mathrm{H}-\mathrm{TaS}_{2}$ phase, with some $1 \mathrm{~T}-\mathrm{TaS}_{2}$ inclusions according to XRD (Fig. S4(a), Supporting Information). A Kelvin probe measurement in air immediately after Ta sulfurization yields a work function of $5.1 \mathrm{eV}$, which is slightly lower than in previous photoemission experiments of $\mathrm{TaS}_{2}$ single-crystals in ultra-high vacuum ${ }^{36}$ and could be affected by adsorbed species. The $\mathrm{TaS}_{2}$ sheet resistance, measured with a four-point probe, is $140 \Omega /$ sq. The corresponding resistivity of $9.8 \times 10^{-3} \Omega \mathrm{cm}$ is higher than in $\mathrm{TaS}_{2}$ single crystals and single layers (in the low $10^{-3} \Omega \mathrm{cm}$ range), ${ }^{39,41}$ possibly due to the pres- 
Table 1: Photovoltaic device parameters of the single-junction and tandem CBTS solar cells presented in this work, compared to the highest efficiency CBTS cell with a Mo back contact and a CdS heterojunction partner known to the authors. ${ }^{6}$

\begin{tabular}{lllll}
\hline Cell & $\begin{array}{l}\eta \\
(\%)\end{array}$ & $\begin{array}{l}V_{\mathrm{oc}} \\
(\mathrm{V})\end{array}$ & $\begin{array}{l}J_{\mathrm{sc}} \\
\left(\mathrm{mA} / \mathrm{cm}^{2}\right)\end{array}$ & $\begin{array}{l}\mathrm{FF} \\
(\%)\end{array}$ \\
\hline CBTS on Mo & 0.98 & 0.55 & 5.4 & 33 \\
CBTS on TaS $_{2}$ & 1.09 & 0.55 & 5.0 & 40 \\
Chen et al. $^{6}$ & 1.72 & 0.70 & 5.2 & 47 \\
CBTS/Si tandem & 0.006 & 0.86 & 0.0048 & 15 \\
\hline
\end{tabular}

ence of grain boundaries and various defects in the thin-film material. Assuming that this $\mathrm{TaS}_{2}$ layer alone was to provide lateral carrier transport at the back contact, its contribution to the series resistance of a solar cell ${ }^{40}$ would still be acceptable (about $0.6 \Omega \mathrm{cm}^{2}$ ) for typical $0.1 \mathrm{~cm}^{2}$ research cells like those fabricated in this study. However, the fill factor of larger cells would be severely degraded, as the lateral spreading resistance contribution to the series resistance of a solar cell scales linearly with area. ${ }^{45}$ Also, the $\mathrm{TaS}_{2}$ film formed in the CBTS solar cell is significantly thinner than the $\mathrm{TaS}_{2}$ film used for electrical measurements, so its sheet resistance may be significantly larger. We then conclude that the unreacted Ta layer (typical sheet resistance: $2 \Omega / \mathrm{sq}$ ) is likely to play an important role in providing a low-resistance path to lateral transport in real solar cells. Although the $\mathrm{Ta}_{\mathrm{x}} \mathrm{O}_{\mathrm{y}}$ layer sandwiched between Ta and $\mathrm{TaS}_{2}$ might not affect the performance of small cells relying on $\mathrm{TaS}_{2}$ for lateral transport, it would probably be detrimental for larger cells, since $\mathrm{Ta}_{2} \mathrm{O}_{5}$ is known to be a very poor conductor. ${ }^{46}$ To prevent formation of $\mathrm{Ta}_{\mathrm{x}} \mathrm{O}_{\mathrm{y}}$, it may be advantageous to pre-sulfurize the Ta layer before CBTO deposition, or employ non-oxide CBTS precursors.

To compare the photovoltaic performance of CBTS with Mo and $\mathrm{TaS}_{2}$ back contacts, solar cells are fabricated with nominally identical $\mathrm{CdS} / \mathrm{ZnO} / \mathrm{ITO}$ electron contacts. As mentioned above, the sulfurization conditions on Ta are constrained by Ta interdiffusion, so the highest-efficiency solar cells are obtained by sulfurization at $540^{\circ} \mathrm{C}$ for $5 \mathrm{~min}$. For the case of CBTS on Mo, the best cells are obtained by sulfurization at $550^{\circ} \mathrm{C}$ for $30 \mathrm{~min}$ using more Cu-poor CBTO precursors (Fig. 1(a)). Current density-voltage (JV) curves and external 

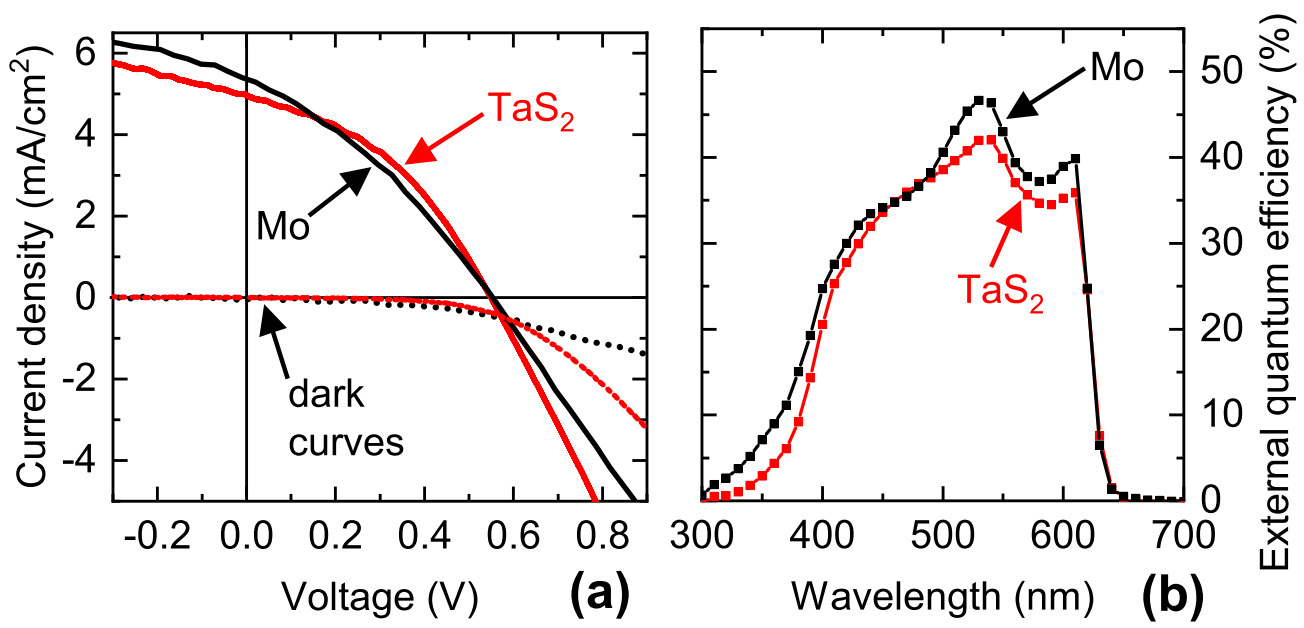

Figure 5: (a): Current density-voltage curves of the highest-efficiency CBTS solar cells on Mo and on $\mathrm{TaS}_{2}$, measured in the dark and under 1-sun illumination. (b): External quantum efficiency (EQE) of the same cells.

quantum efficiency (EQE) spectra of the best solar cells on Mo and on $\mathrm{TaS}_{2}$ are shown in Fig. 5. Photovoltaic parameters of the best cells are listed in Table 1 and statistical data is presented in Fig. 6. The main difference between the two back contacts is the consistently higher FF achieved with $\mathrm{TaS}_{2}$ (Fig. 6(d)). As for the case of the $\mathrm{Au} / \mathrm{MoO}_{3}$ back contact developed for CZTS cells ${ }^{18}$ the FF improvement can be primarily attributed to a decrease in series resistance (Fig. 5(a)). A possible reason for the lower series resistance is the direct contact of CBTS with a metallic material $\left(\mathrm{TaS}_{2}\right)$ having a higher conductivity than $\mathrm{MoS}_{2}$ by roughly 5-6 orders of magnitude. ${ }^{39,41,47} V_{\text {oc }}$ is identical in the two best cells, with slightly higher average values obtained with $\mathrm{TaS}_{2}$ (Fig. 6(c)). On the other hand, $J_{\text {sc }}$ is consistently lower for the $\mathrm{TaS}_{2}$ back contact (Fig. 6(b)). A possible explanation is the increased presence of voids and secondary phases when CBTS is grown on Ta (Figs. 2, 3(e)), causing increased recombination independently of the applied voltage. As the FF gain is larger than the $J_{\mathrm{sc}}$ loss, the $\mathrm{TaS}_{2}$ back contact yields a slightly higher efficiency than the conventional Mo back contact (Fig. 6(a)). 


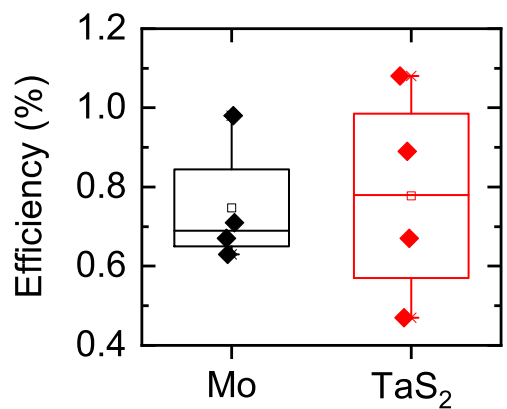

(a)

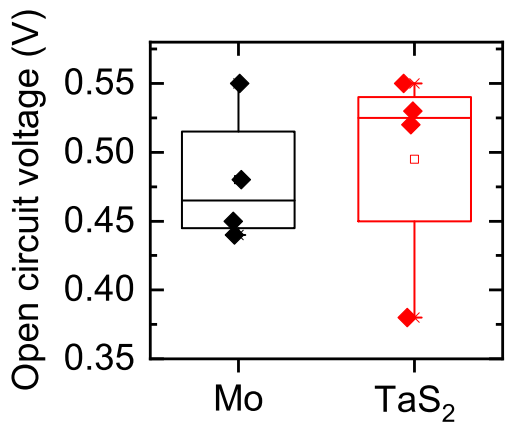

(c)

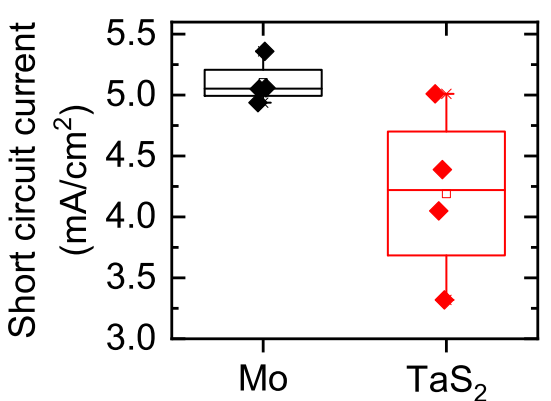

(b)

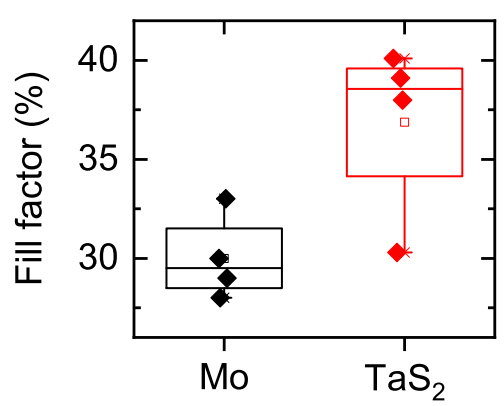

(d)

Figure 6: Efficiency (a), short circuit current (b), open circuit voltage (c) and fill factor (d) of the four solar cells present on the chip containing the highest-efficiency cell for each back contact type.

\section{CBTS/Si tandem solar cell}

Only very few experimental realizations of monolithic tandem cells employing any chalcogenide absorber on top of silicon have been reported. ${ }^{20-23}$ Although CBTS technology is not sufficiently mature for realizing efficient tandem cells, it is of interest to examine potential compatibility issues with a $\mathrm{Si}$ bottom cell and evaluate prospective recombination layers between the two subcells. For those reasons, fabrication of a monolithic CBTS/Si tandem solar cell is attempted. The full fabrication process is detailed in the Supporting Information. Briefly, the silicon bottom cell (Fig. 7) consists of an n-type crystalline Si (c-Si) absorber passivated by a tunnel oxide $\left(1.2 \mathrm{~nm} \mathrm{SiO}_{2}\right)$ on each side, with highly n- and p-type doped polycrystalline Si layers (40 nm n + and $\mathrm{p}+$ polySi) as electron- and hole contacts respectively. The choice of material to be used as a recombination layer between the Si bottom cell and the CBTS top cell is not trivial. The ideal material must posses a reasonably high 

band gaps, it must be stable in a sulfur-containing atmosphere above $500^{\circ} \mathrm{C}$, and it must prevent contamination of the $\mathrm{Si}$ wafer with $\mathrm{Cu}, \mathrm{Ba}, \mathrm{Sn}$, and $\mathrm{S}$. In view of its good thermal stability, transparency and conductivity, FTO could be a suitable option, especially because single-junction CBTS solar cells on FTO have been demonstrated before. ${ }^{5}$ Nevertheless, our attempts to grow CBTS on FTO failed due to nearly complete intermixing of the two materials during sulfurization (Fig. S8, Supporting Information). We speculate that intermixing might be facilitated when both species (FTO and CBTO) are oxides, compared to the case of CBTS precursors in sulfide form.

As an alternative recombination layer material, we employ a thin $\operatorname{Ti}(\mathrm{O}, \mathrm{N})$ layer deposited by atomic layer deposition (ALD) as proposed recently. ${ }^{22} \mathrm{TiN}$ is a well-known diffusion barrier in Si-based technology ${ }^{48}$ and has been employed as a back contact/diffusion barrier in CZTS solar cells. ${ }^{29,33,49,50}$ As TiN is a metallic compound, its optical transmission is inherently low and could severely limit the photon flux reaching the silicon subcell. Thus, a thin $(25 \mathrm{~nm}) \operatorname{Ti}(\mathrm{O}, \mathrm{N})$ layer with $\mathrm{N} /(\mathrm{O}+\mathrm{N}) \sim 0.4$ is employed to ensure a high average transmission of $85 \%$ between the band gap energies of Si and CBTS (Fig. S9, Supporting Information). CBTO precursors with the same composition as in the highest-efficiency cells on $\mathrm{TaS}_{2}$ (Fig. 1(a)) are then deposited on $\mathrm{Ti}(\mathrm{O}, \mathrm{N})$, sulfurized at $540^{\circ} \mathrm{C}$ for $5 \mathrm{~min}$, and coated with the $\mathrm{CdS} / \mathrm{ZnO} / \mathrm{ITO}$ top layers as in the single-junction cells. Higher sulfurization temperatures and longer times are avoided in an attempt to minimize damage to the Si bottom cell. Finally, a Ag back contact is sputter-deposited on the back side. More fabrication details are given in the Supporting Information.

Grazing-incidence XRD patterns of a CBTS film on $\mathrm{Ti}(\mathrm{O}, \mathrm{N}) / \mathrm{Si}$ (Fig. 2) show trigonal CBTS as the main phase, with some Si peaks from the substrate, as well as several peaks from secondary phases. However, peaks from the $\mathrm{Ba}_{2} \mathrm{SnS}_{4}$ secondary phase that was predominant for the case of the Mo and $\mathrm{TaS}_{2}$ back contacts are absent. Instead, the spurious peaks are broader and more intense, and can be attributed to $\mathrm{Cu}_{4} \mathrm{BaS}_{3}$ or $\mathrm{BaSn}_{2} \mathrm{~S}_{3}$, or both (Fig. $\mathrm{S} 3$, 
Supporting Information). By increasing the incidence angle in grazing-incidence XRD (larger analysis depth), the relative intensity of the spurious peaks increases with respect to the CBTS peaks (Fig. 2), indicating that the secondary phases are present in larger quantities at the bottom of CBTS. This is confirmed by cross-sectional SEM images, as nanocrystalline secondary phases are clearly visible near the Ti(O,N)/CBTS interface in Fig. 3(i). Secondary phases with $\mathrm{Cu}_{4} \mathrm{BaS}_{3}$ stoichiometry are also confirmed by point EDX spectra for the rare cases in which those phases are visible from top-view SEM images (Fig. S10, Supporting Information). The main difference between growing CBTS on a SLG substrate and on a Si substrate is that no $\mathrm{Na}$ is available to assist CBTS growth in the latter case. The lack of $\mathrm{Na}$ probably plays a role ${ }^{30}$ in the smaller grain size observed for CBTS in the tandem structure (Fig. 3(c)). Since Na is known to aid the crystallization process in related materials ${ }^{30}$ and a $\mathrm{Cu}$-rich ternary phase is not expected in a strongly $\mathrm{Cu}$-poor film, it is possible that the back side of the film needs a higher temperature or longer time for the CBTS-forming reaction to be completed in the absence of Na. In fact, the film morphology in Fig. 3(f) is similar to the morphology of a CSTS film grown by the same method but sulfurized at a lower temperature $\left(520^{\circ} \mathrm{C}\right)$ in the presence of $\mathrm{Na}^{25}$

The presence of $\mathrm{Cu}_{4} \mathrm{BaS}_{3}$ and/or $\mathrm{BaSn}_{2} \mathrm{~S}_{3}$ phases may be an important factor behind the poor performance of the CBTS/Si tandem cell (Fig. 7). Unlike the $\mathrm{Ba}_{2} \mathrm{SnS}_{4}$ phase found in the single-junction cells, $\mathrm{Cu}_{4} \mathrm{BaS}_{3}$ has a lower band gap than CBTS $(1.8 \mathrm{eV} \text { versus } 2.0 \mathrm{eV})^{51}$ and may therefore act as a trap for the carriers generated in CBTS. $\mathrm{BaSn}_{2} \mathrm{~S}_{3}$ may cause similar effects, although the only reported band gap (1.3 eV) was calculated with a method prone to band gap underestimation. ${ }^{32}$ The $V_{\text {oc }}$ of the tandem cell $(0.86 \mathrm{~V})$ indicates that a (poor) series connection between the top and bottom cell has been established, since the value is higher than the $V_{\text {oc }}$ expected for each individual cell based on the single-junction cell results (Table 1). The tandem cell exhibits an extremely pronounced roll-over effect with a very small photocurrent under forward bias and a rapidly increasing photocurrent under reverse bias (Fig. 7). A similar effect was observed for CZTS tandem cells with the same 
Figure 7: Device architecture and current density-voltage curves of a CBTS/Si tandem solar cell, measured in the dark and under 1-sun illumination.

device structure. ${ }^{22}$ As a consequence, both $J_{\text {sc }}$ and FF are very low and the efficiency is negligible. The roll-over effect is usually attributed to a barrier to carrier transport ${ }^{52}$ which, in the case of the present CBTS/Si tandem, must be so large that it can only be partially overcome under reverse bias. Two explanations may be plausible here: (i) photogenerated holes near the bottom of the CBTS film are trapped in the $\mathrm{Cu}_{4} \mathrm{BaS}_{3} / \mathrm{BaSn}_{2} \mathrm{~S}_{3}$ phases and can only escape under a high electric field; (ii) there is a barrier at the $\mathrm{Ti}(\mathrm{O}, \mathrm{N}) /$ PolySi interface or at the $\mathrm{Ti}(\mathrm{O}, \mathrm{N}) / \mathrm{CBTS}$ interface. We note that the pure oxide $\mathrm{TiO}_{2}$ is typically used as an electron contact, even for CBTS devices, ${ }^{10,53}$ so the $\mathrm{Ti}(\mathrm{O}, \mathrm{N}) / \mathrm{CBTS}$ hole contact may be the most likely location of a barrier to carrier transport.

While the overall performance of the present CBTS/Si tandem cell is severely limited by very poor photocurrent collection, a few simple changes in the fabrication process might result in significant improvement. Limited grain growth and unexpected secondary phases in CBTS may be prevented by intentional inclusion of a thin Na-containing layer before sulfu- 
rization, as already demonstrated for CBTS single-junction cells ${ }^{5}$ and for CZTS/Si tandem cells. ${ }^{23}$ The barrier to carrier transport might be mitigated by decreasing the oxygen content of $\operatorname{Ti}(\mathrm{O}, \mathrm{N})$, although the layer would probably have to be kept thinner to avoid transmission losses due to the metallic character of TiN. Encouragingly, detailed characterization ${ }^{22}$ has shown that the minority carrier lifetime of the bottom Si cell is nearly unaffected by the sulfurization process even for very thin TiN films.

\section{Conclusion}

Sulfurization of reactively sputtered $\mathrm{Cu}_{2} \mathrm{BaSnO}_{4}$ precursors was shown to be a viable process route for the growth of $\mathrm{Cu}_{2} \mathrm{BaSnS}_{4}$ photovoltaic absorbers, circumventing the need for ceramic targets and the introduction of sulfur in vacuum system. Complete substitution of oxygen by sulfur and formation of the trigonal CBTS crystal stucture were achieved at around the same sulfurization temperature as for the case of sulfide/metallic starting precursors. The grain size, band gap and PL features were similar to previously reported CBTS films from sulfide/metallic sputtered precursors. Surprisingly, the composition of the CBTO precursors giving the most efficient solar cells was more $\mathrm{Cu}$-poor than the desired composition of the final CBTS films, especially at high sulfurization temperatures and long times. Consequently, $\mathrm{Ba}_{2} \mathrm{SnS}_{4}$ secondary phases were observed in the bottom half of the film. CBTS solar cells from oxide precursors achieved the same $J_{\text {sc }}$ as the current state-of-the-art CBTS solar cells, but lower $V_{\text {oc }}$ and FF. The high work-function metallic compound $\mathrm{TaS}_{2}$ was proposed as a possible replacement for the standard Mo back contact in CBTS solar cells. Interestingly, cells on $\mathrm{TaS}_{2}$ yielded slightly higher efficiencies than cells on Mo, mostly due to an improved FF and series resistance. The oxide precursor route to CBTS synthesis might, however, not be optimal in conjunction with a $\mathrm{TaS}_{2}$ back contact due to the risk of formation of an insulating $\mathrm{Ta}_{\mathrm{x}} \mathrm{O}_{\mathrm{y}}$ interlayer. Finally, fabrication of a monolithic tandem cell with a CBTS top absorber and a Si bottom absorber was attempted, using a thin $\mathrm{Ti}(\mathrm{O}, \mathrm{N})$ recombi- 


\section{Supporting Information}

Extended experimental details, basic characterization of CBTO precursors, additional XRD patterns of CBTS, CSTS, and $\mathrm{TaS}_{2}$, CBTS band gap estimation, additional SEM images, optical transmission spectrum of $\operatorname{Ti}(\mathrm{O}, \mathrm{N})$, identification of secondary phases in CBTS grown on the Si bottom cell.

\section{Acknowledgements}

This work was supported by VILLUM Fonden (grant no. 9455) and the Innovation Fund Denmark (grant no. 6154-00008A).

\section{References}

(1) Green, M. A. Commercial progress and challenges for photovoltaics. Nature Energy 2016, 1, 15015.

(2) Liu, Z.; Krückemeier, L.; Krogmeier, B.; Klingebiel, B.; Márquez, J. A.; Levcenko, S.; Öz, S.; Mathur, S.; Rau, U.; Unold, T.; Kirchartz, T. Open-Circuit Voltages Exceeding 
1.26 V in Planar Methylammonium Lead Iodide Perovskite Solar Cells. ACS Energy Letters 2019, 4, 110-117.

(3) Burst, J. M.; Duenow, J. N.; Albin, D. S.; Colegrove, E.; Reese, M. O.; Aguiar, J. A.; Jiang, C.-S.; Patel, M. K.; Al-Jassim, M. M.; Kuciauskas, D.; Swain, S.; Ablekim, T.; Lynn, K. G.; Metzger, W. K. CdTe solar cells with open-circuit voltage breaking the 1 V barrier. Nature Energy 2016, 1, 16015.

(4) Larsson, F.; Nilsson, N. S.; Keller, J.; Frisk, C.; Kosyak, V.; Edoff, M.; Törndahl, T. Record 1.0 V open-circuit voltage in wide band gap chalcopyrite solar cells. Progress in Photovoltaics: Research and Applications 2017, 25, 755-763.

(5) Ge, J.; Koirala, P.; Grice, C. R.; Roland, P. J.; Yu, Y.; Tan, X.; Ellingson, R. J.; Collins, R. W.; Yan, Y. Oxygenated CdS Buffer Layers Enabling High Open-Circuit Voltages in Earth-Abundant $\mathrm{Cu}_{2} \mathrm{BaSnS}_{4}$ Thin-Film Solar Cells. Advanced Energy Materials 2017, 7, 1601803.

(6) Chen, Z.; Sun, K.; Su, Z.; Liu, F.; Tang, D.; Xiao, H.; Shi, L.; Jiang, L.; Hao, X.; Lai, Y. Solution-Processed Trigonal $\mathrm{Cu}_{2} \mathrm{BaSnS}_{4}$ Thin-Film Solar Cells. ACS Applied Energy Materials 2018, 1, 3420-3427.

(7) Shin, D.; Saparov, B.; Zhu, T.; Huhn, W. P.; Blum, V.; Mitzi, D. B. BaCu 2 Sn(S,Se) 4 : Earth-Abundant Chalcogenides for Thin-Film Photovoltaics. Chemistry of Materials 2016, 28, 4771-4780.

(8) Guo, H.; Ma, C.; Chen, Z.; Jia, X.; Cang, Q.; Yuan, N.; Ding, J. The fabrication of $\mathrm{Cu}_{2} \mathrm{BaSnS}_{4}$ thin film solar cells utilizing a maskant layer. Solar Energy 2019, 181, $301-307$.

(9) Sun, J.-P.; Márquez, J. A.; Stange, H.; Mainz, R.; Mitzi, D. B. Phase and film formation pathway for vacuum-deposited $\mathrm{Cu}_{2} \operatorname{BaSn}(\mathrm{S}, \mathrm{Se})_{4}$ absorber layers. Physical Review Materials 2019, 3, 055402. 
(10) Ge, J.; Roland, P. J.; Koirala, P.; Meng, W.; Young, J. L.; Petersen, R.; Deutsch, T. G.; Teeter, G.; Ellingson, R. J.; Collins, R. W.; Yan, Y. Employing Overlayers To Improve the Performance of $\mathrm{Cu}_{2} \mathrm{BaSnS}_{4}$ Thin Film based Photoelectrochemical Water Reduction Devices. Chemistry of Materials 2017, 29, 916-920.

(11) Ge, J.; Yan, Y. Synthesis and characterization of photoelectrochemical and photovoltaic $\mathrm{Cu}_{2} \mathrm{BaSnS}_{4}$ thin films and solar cells. Journal of Materials Chemistry $C$ 2017, 5, 64066419.

(12) Hong, F.; Lin, W.; Meng, W.; Yan, Y. Trigonal $\mathrm{Cu}_{2}-\mathrm{II}-\mathrm{Sn}-\mathrm{VI}_{4}$ (II = Ba, Sr and VI $=\mathrm{S}, \mathrm{Se}$ ) quaternary compounds for earth-abundant photovoltaics. Physical Chemistry Chemical Physics 2016, 18, 4828-4834.

(13) Teske, C. L.; Vetter, O. Präparative und röntgenographische Untersuchung am System $\mathrm{Cu}_{2-x} \mathrm{Ag}_{x} \mathrm{BaSnS}_{4}$. Zeitschrift für anorganische und allgemeine Chemie 1976, 426, 281287.

(14) Shin, B.; Gunawan, O.; Zhu, Y.; Bojarczuk, N. A.; Chey, S. J.; Guha, S. Thin film solar cell with $8.4 \%$ power conversion efficiency using an earth-abundant $\mathrm{Cu}_{2} \mathrm{ZnSnS}_{4}$ absorber. Progress in Photovoltaics: Research and Applications 2013, 21, 72-76.

(15) Cazzaniga, A.; Crovetto, A.; Yan, C.; Sun, K.; Hao, X.; Ramis Estelrich, J.; Canulescu, S.; Stamate, E.; Pryds, N.; Hansen, O.; Schou, J. Ultra-thin $\mathrm{Cu}_{2} \mathrm{ZnSnS}_{4}$ solar cell by pulsed laser deposition. Solar Energy Materials and Solar Cells 2017, 166, 91-99.

(16) Larramona, G.; Levcenko, S.; Bourdais, S.; Jacob, A.; Choné, C.; Delatouche, B.; Moisan, C.; Just, J.; Unold, T.; Dennler, G. Fine-Tuning the Sn Content in CZTSSe Thin Films to Achieve 10.8\% Solar Cell Efficiency from Spray-Deposited WaterEthanol-Based Colloidal Inks. Advanced Energy Materials 2015, 5, 1501404. 
(17) Mirbagheri, N.; Engberg, S.; Crovetto, A.; Simonsen, S. B.; Hansen, O.; Lam, Y. M.; Schou, J. Synthesis of ligand-free CZTS nanoparticles via a facile hot injection route. Nanotechnology 2016, 2\%, 185603.

(18) Antunez, P. D.; Bishop, D. M.; Luo, Y.; Haight, R. Efficient kesterite solar cells with high open-circuit voltage for applications in powering distributed devices. Nature Energy 2017, 2, 884-890.

(19) Larsen, J. K.; Larsson, F.; Törndahl, T.; Saini, N.; Riekehr, L.; Ren, Y.; Biswal, A.; Hauschild, D.; Weinhardt, L.; Heske, C.; Platzer-Björkman, C. Cadmium Free $\mathrm{Cu}_{2} \mathrm{ZnSnS}_{4}$ Solar Cells with 9.7\% Efficiency. Advanced Energy Materials 2019, 9, 1900439.

(20) Noufi, R.; Young, D. L.; Coutts, T. J.; Gessert, T. A.; Ward, J. S.; Duda, A.; Wu, X.; Romero, M.; Dhere, R.; Abu Shama, J. Toward a 25\%-efficient polycrystalline thin-film tandem solar cell: practical issues. Proceedings of 3rd World Conference on Photovoltaic Energy Conversion. Osaka, Japan, 2003; pp 12-14.

(21) Jeong, A. R.; Choi, S. B.; Kim, W. M.; Park, J.-K.; Choi, J.; Kim, I.; Jeong, J.-H. Electrical analysis of c-Si/CGSe monolithic tandem solar cells by using a cell-selective light absorption scheme. Scientific Reports 2017, 7, 15723.

(22) Hajijafarassar, A.; Martinho, F.; Stulen, F.; Grini, S.; Lopez-Marino, S.; EspindolaRodríguez, M.; Dobeli, M.; Canulescu, S.; Stamate, E.; Gansukh, M.; Engberg, S.; Crovetto, A.; Vines, L.; Schou, J.; Hansen, O. Monolithic Thin-Film ChalcogenideSilicon Tandem Solar Cells Enabled by a Diffusion Barrier. Solar Energy Materials and Solar Cells, accepted

(23) Valentini, M.; Malerba, C.; Serenelli, L.; Izzi, M.; Salza, E.; Tucci, M.; Mittiga, A. Fabrication of monolithic CZTS/Si tandem cells by development of the intermediate connection. Solar Energy 2019, 190, 414-419. 
(27) Redinger, A.; Berg, D. M.; Dale, P. J.; Siebentritt, S. The Consequences of Kesterite Equilibria for Efficient Solar Cells. Journal of the American Chemical Society 2011, 133, 3320-3323.

(28) Rumble, J. R. In CRC Handbook of Chemistry and Physics, 100th Edition; Rumble, J. R., Ed.; CRC Press, 2019.

(29) Scragg, J. J.; Kubart, T.; Wätjen, J. T.; Ericson, T.; Linnarsson, M. K.; PlatzerBjörkman, C. Effects of Back Contact Instability on $\mathrm{Cu}_{2} \mathrm{ZnSnS}_{4}$ Devices and Processes. Chemistry of Materials 2013, 25, 3162-3171.

(30) Gershon, T.; Shin, B.; Bojarczuk, N.; Hopstaken, M.; Mitzi, D. B.; Guha, S. The Role of Sodium as a Surfactant and Suppressor of Non-Radiative Recombination at Internal Surfaces in $\mathrm{Cu}_{2} \mathrm{ZnSnS}_{4}$. Advanced Energy Materials 2014, 5, 1400849.

(31) Giraldo, S.; Saucedo, E.; Neuschitzer, M.; Oliva, F.; Placidi, M.; Alcobé, X.; IzquierdoRoca, V.; Kim, S.; Tampo, H.; Shibata, H.; Pérez-Rodríguez, A.; Pistor, P. How small amounts of Ge modify the formation pathways and crystallization of kesterites. Energy 83 Environmental Science 2018, 11, 582-593. 
(32) Jain, A.; Ong, S. P.; Hautier, G.; Chen, W.; Richards, W. D.; Dacek, S.; Cholia, S.; Gunter, D.; Skinner, D.; Ceder, G.; Persson, K. A. Commentary: The Materials Project: A materials genome approach to accelerating materials innovation. APL Materials 2013, 1, 011002.

(33) Platzer-Björkman, C.; Barreau, N.; Bär, M.; Choubrac, L.; Grenet, L.; Heo, J.; Kubart, T.; Mittiga, A.; Sanchez, Y.; Scragg, J.; Sinha, S.; Valentini, M. Back and front contacts in kesterite solar cells: state-of-the-art and open questions. Journal of Physics: Energy 2019, 1, 044005.

(34) Friedlmeier, T. M.; Jackson, P.; Bauer, A.; Hariskos, D.; Kiowski, O.; Menner, R.; Wuerz, R.; Powalla, M. High-efficiency Cu(In,Ga)Se ${ }_{2}$ solar cells. Thin Solid Films 2017, 633, $13-17$.

(35) Tai, K. F.; Gunawan, O.; Kuwahara, M.; Chen, S.; Mhaisalkar, S. G.; Huan, C. H. A.; Mitzi, D. B. Fill Factor Losses in $\mathrm{Cu}_{2} \mathrm{ZnSn}\left(\mathrm{S}_{x} \mathrm{Se}_{1-x}\right)_{4}$ Solar Cells: Insights from Physical and Electrical Characterization of Devices and Exfoliated Films. Advanced Energy Materials 2016, 6, 1501609 .

(36) Shimada, T.; Ohuchi, F. S.; Parkinson, B. A. Work Function and Photothreshold of Layered Metal Dichalcogenides. Japanese Journal of Applied Physics 1994, 33, 26962698.

(37) Kraft, D.; Weiler, U.; Tomm, Y.; Thissen, A.; Klein, A.; Jaegermann, W. Alternative back contacts for CdTe solar cells: a photoemission study of the $\mathrm{VSe}_{2} / \mathrm{CdTe}$ and $\mathrm{TiSe}_{2} /$ CdTe interface formation. Thin Solid Films 2003, 431-432, 382-386.

(38) Wolak, M. A.; Gutmann, S.; Conrad, M.; Beerbom, M. M.; Ferekides, C.; Schlaf, R. Charge injection barriers and chemical interaction at the $\mathrm{CdTe} / \mathrm{NbSe}_{2}$ interface. Journal of Applied Physics 2011, 109, 023701. 
(44) Crovetto, A.; Nielsen, R.; Pandey, M.; Watts, L.; Labram, J. G.; Geisler, M.; Stenger, N.; Jacobsen, K. W.; Hansen, O.; Seger, B.; Chorkendorff, I.; Vesborg, P. C. K. Shining Light on Sulfide Perovskites: $\mathrm{LaYS}_{3}$ Material Properties and Solar Cells. Chemistry of Materials 2019, 31, 3359-3369.

(45) Kneisel, J.; Siemer, K.; Luck, I.; Bräunig, D. Admittance spectroscopy of efficient $\mathrm{CuInS}_{2}$ thin film solar cells. Journal of Applied Physics 2000, 88, 5474.

(46) Aris, F. C.; Lewis, T. J. Steady and transient conduction processes in anodic tantalum oxide. Journal of Physics D: Applied Physics 1973, 6, 311.

(47) El-Mahalawy, S. H.; Evans, B. L. Temperature dependence of the electrical conductivity and hall coefficient in $2 \mathrm{H}-\mathrm{MoS}_{2}, \mathrm{MoSe}_{2}, \mathrm{WSe}_{2}$, and $\mathrm{MoTe}_{2}$. Physica Status Solidi (b) 1977, $79,713-722$. 
(48) Kaloyeros, A. E.; Eisenbraun, E. Ultrathin Diffusion Barriers/Liners for Gigascale Copper Metallization. Annual Review of Materials Science 2000, 30, 363-385.

(49) Englund, S.; Grini, S.; Donzel-Gargand, O.; Paneta, V.; Kosyak, V.; Primetzhofer, D.; Scragg, J. J. S.; Platzer-Björkman, C. TiN Interlayers with Varied Thickness in $\mathrm{Cu}_{2} \mathrm{ZnSnS}(\mathrm{e})_{4}$ Thin Film Solar Cells: Effect on Na Diffusion, Back Contact Stability, and Performance. physica status solidi (a) 2018, 215, 1800491.

(50) Schnabel, T.; Ahlswede, E. On the interface between kesterite absorber and Mo back contact and its impact on solution-processed thin-film solar cells. Solar Energy Materials and Solar Cells 2017, 159, 290-295.

(51) Han, Y.; Siol, S.; Zhang, Q.; Zakutayev, A. Optoelectronic Properties of Strontium and Barium Copper Sulfides Prepared by Combinatorial Sputtering. Chemistry of Materials 2017, 29, 8239-8248.

(52) Saive, R. S-Shaped Current-Voltage Characteristics in Solar Cells: A Review. IEEE Journal of Photovoltaics 2019, 1-8.

(53) Plakhotnyuk, M. M.; Schüler, N.; Shkodin, E.; Vijayan, R. A.; Masilamani, S.; Varadharajaperumal, M.; Crovetto, A.; Hansen, O. Surface passivation and carrier selectivity of the thermal-atomic-layer-deposited $\mathrm{TiO}_{2}$ on crystalline silicon. Japanese Journal of Applied Physics 2017, 56, 08MA11. 


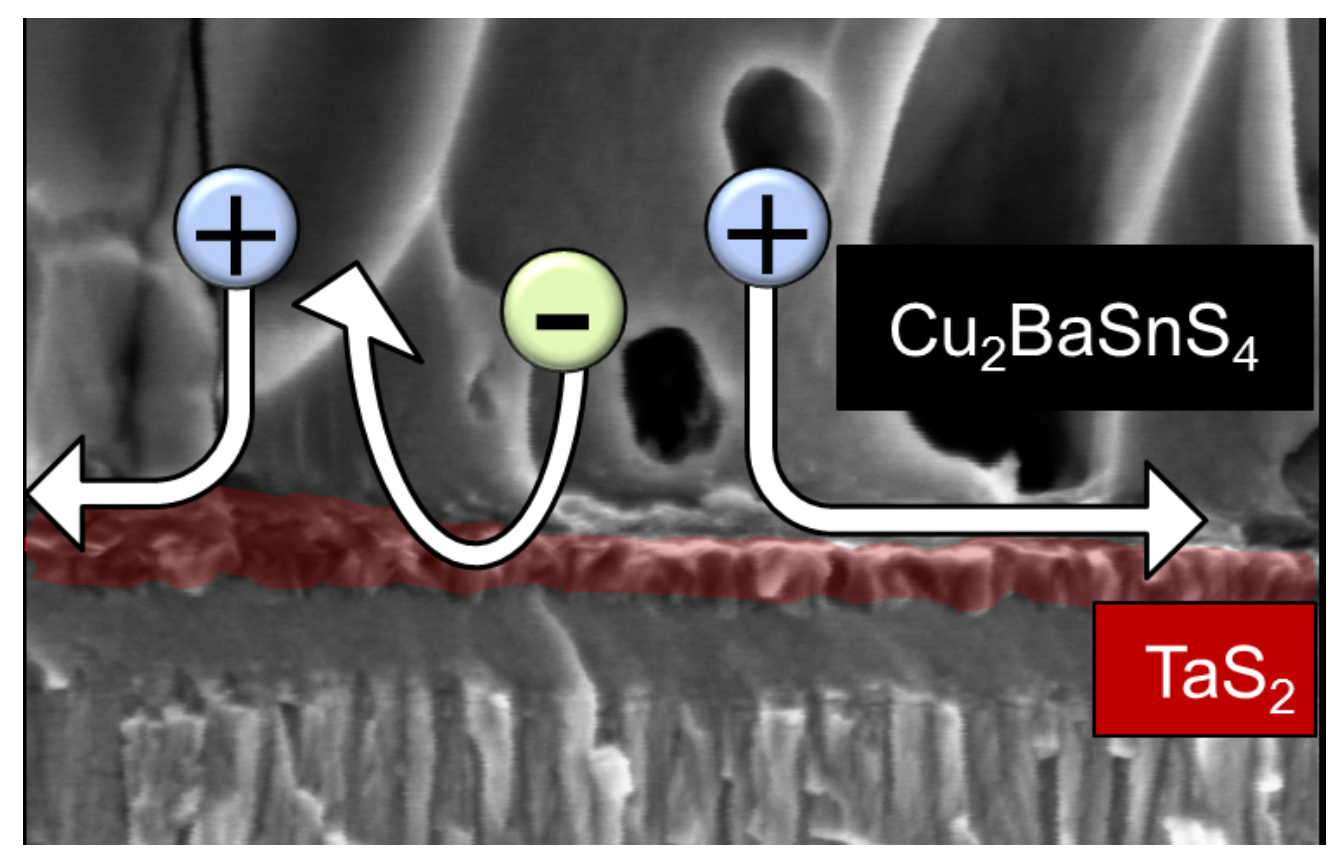

$127 \times 80 \mathrm{~mm}(150 \times 150 \mathrm{DPI})$ 